\title{
Cyclical Analysis of Trade Dynamics In Nigeria
}

\author{
ThankGod 0. Apere \\ Department of Economics, Niger Delta University, \\ Wilberforce Island, P.M.B 071, Bayelsa State, Nigeria \\ Tamarauntari M. Karimo \\ Department of Economics, Niger Delta University, \\ Wilberforce Island, P.M.B 071, Bayelsa State, Nigeria
}

\begin{abstract}
This study using first differenced VAR(1) model attempted a cyclical analysis of trade dynamics in Nigeria over the period 1981 - 2012. Two historical business cycle troughs in 1985 and 2001 were identified. Results showed no evidence supporting the assertion that non-oil trade has contributed to economic recoveries in Nigeria. Furthermore nominal shocks dominated output shocks in explaining changes in trade variables. It was therefore recommended that, to better tap from the global resource base the monetary authority in Nigeria should apply sound monetary policy during periods of recession to stimulate output growth and quick recovery.
\end{abstract}

Key Words: Cyclical Analysis, Trade Dynamics, VAR, Shocks, Non-oil trade.

\section{INTRODUCTION}

There is no gainsaying the fact that no country is self-sufficient in terms of goods and services needed to meet the daily needs of raw materials and capital goods for her industries, and finished goods for consumers. This has led to specialization and inevitably trade as espoused by trade theories. Trade has become a standard (norm) in the world system today. As economies become more open to international trade the propagation and transmission of economic fluctuations through trade is increasingly assuming a more important dimensions. This underscores the importance of cyclical analysis of trade dynamics in Nigeria. This has important policy implications in terms of macroeconomic forecasting, short-run policy making and international policy coordination.

\section{The Extent of Trade in Nigeria}

\section{STYLIZED FACTS}

First this paper examined the economic importance of trade to the Nigerian economy. One important indicator that is widely used as a measure for an economy's openness to international trade is total trade to real GDP ratio. Between 1981 and 2012 the mean value of this ratio as shown in the first column and the last row of Table 1 was $1.34 \mathrm{E}-05$. The mean value of this ratio in different subsamples as showed in the first row of Table 1 increased gradually from 4.68E-07 in the period 1981 - 1989 to $7.89 \mathrm{E}-06$ between 1990 and 1999, and further to $2.65 \mathrm{E}-05$ in the period $2000-2012$. Although the average values of this ratio in the full- and sub-samples is very small, they reflect the growing importance of trade to the Nigerian economy. Also, the mean value of both non-oil and oil trade to real GDP ratio in columns 2 and 3 of Table 1 increased throughout the subsamples reinforcing the previous assertion. Whereas oil trade increased rapidly from 0.07 in 1981 - 1989 to 1.7 in 1990 - 1999 and further to 10.9 in 2000 - 2012 and average 5.55 between 1981 and 2012, non-oil trade 
increased slowly from 0.05 to 0.98 and further to 4.96 in the same periods and averaged 2.33 between 1981 and 2012. This showed that oil-trade has been more important to the Nigerian economy compared to non-oil trade. Furthermore, total export, non-oil export and oil export as shown in columns 4, 5 and 6 contributed little to real GDP between 1981 and 2012, respectively. However, their importance to the Nigerian economy has been on the increase. Whereas non-oil export increased from 0.004 to 1.4 and 10.6 in the periods $1981-1989,1990$ - 1999 and 2000 - 2012 respectively oil export increased within the same period from 0.069 to 1.93 and 12.12 .

The foregoing is a clear evidence of the growing importance of trade (oil and non-oil trade) to the Nigerian economy since 1981. Therefore a good knowledge or understanding of the role of trade in enhancing or dampening domestic macroeconomic fluctuations is of immense importance as the country becomes more and more entangled in the web of the world system through trade.

Table 1: Measures of Trade Openness

\begin{tabular}{ccccccc}
\hline & TT/GDP & NOT/GDP & OT/GDP & X/GDP & NOX/GDP & OX/GDP \\
\hline $1981-1989$ & $4.68 \mathrm{E}-07$ & 0.050705 & 0.074555 & 0.072222 & 0.004125 & 0.069094 \\
$1990-1999$ & $7.89 \mathrm{E}-06$ & 0.980349 & 1.707000 & 1.707000 & 1.400000 & 1.930656 \\
$2000-2012$ & $2.65 \mathrm{E}-05$ & 4.955528 & 10.90154 & 0.300914 & 10.60004 & 12.13452 \\
Full Sample & $1.34 \mathrm{E}-05$ & 2.3338 & 5.553949 & 4.9825 & 0.136227 & 4.845928 \\
\hline
\end{tabular}

Source: Author's Computation using figures from CBN Statistical Bulletin, 2012

\section{Unconditional Volatility of Trade Variables}

Now turn to the unconditional volatility of trade variables as measured by the standard deviation of various quantities and price relevant to trade dynamics relative to Nigeria's business cycle. Real GDP and nominal effective exchange rate values were first transformed into logarithms and their cyclical components were derived using the Hodrick-Prescott (HP) filter. The trade variables to GDP ratio were also transformed using the HP filter. This method had been previously used by Prasad \& Gable (1998) to examine the determinants of trade dynamics in the OECD economies. The first and second columns of Table 2 contain the standard deviations of domestic output and net export to GDP ratio. The figures generally showed that net export is more volatile compared to aggregate output. Columns 3 and 4 show that net non-oil export is less volatile than net oil export. Furthermore, Import is less volatile than export. Finally, nominal effective exchange rate is more volatile than output and net nonoil export but less than net oil export. One important observation about the dynamics of trade balance is that the pattern of shock is largely the same over time. Short-run trade dynamics could depend on shocks that drive business cycle fluctuations.

Table 2: Measures of Volatility of Cyclical Components

\begin{tabular}{cccccccc}
\hline & GDP & $\begin{array}{c}\text { Net } \\
\text { Export/GDP }\end{array}$ & $\begin{array}{c}\text { Net Non-Oil } \\
\text { Export/GDP }\end{array}$ & $\begin{array}{c}\text { Net Oil } \\
\text { Export/GDP }\end{array}$ & Import/GDP & Export/GDP & NEER \\
\hline $1981-1989$ & 0.050 & 0.014 & 0.014 & 0.027 & 0.019 & 0.032 & 0.430 \\
$1990-1999$ & 0.011 & 0.596 & 0.307 & 0.682 & 0.380 & 0.750 & 1.040 \\
$2000-2012$ & 0.009 & 1.654 & 0.606 & 1.514 & 0.869 & 1.573 & 0.092 \\
Full Sample & 0.036 & 1.119 & 0.415 & 1.071 & 0.577 & 1.121 & 0.645 \\
\hline
\end{tabular}

Source: Authors' Computation

\section{Unconditional Correlations}

This paper also examined the unconditional correlation between the cyclical components of output and the various trade variables. The paper specifically examined the contemporaneous correlations as well as correlations at various leads and lags to explore the dynamic patterns in 
the data. The first row of table 3 shows the correlation between the cyclical components of output and net exports. The negative values at lead 8 and 4 (positive (negative) values in the lead row indicate lead (lag)) and positive values at lag 0,4 and 8 indicate net export is countercyclical during recoveries and procyclical contemporaneously and during periods of recession.

Table 3: Correlations of Trade Variables and the Business Cycle

\begin{tabular}{llllll}
\hline Lead: & 8 & 4 & 0 & -4 & -8 \\
\hline GDP, net export/GDP & -0.18 & -0.08 & 0.15 & 0.03 & 0.003 \\
GDP, import/GDP & -0.02 & 0.14 & -0.02 & -0.28 & 0.27 \\
GDP, export/GDP & -0.19 & -0.0007 & 0.14 & -0.05 & 0.11 \\
GDP, net non-oil export/GDP & 0.12 & -0.14 & 0.01 & 0.23 & -0.27 \\
GDP, net oil export/GDP & -0.23 & -0.03 & 0.15 & -0.02 & 0.09 \\
\hline
\end{tabular}

Source: Authors' Computation

\section{International Trade and Business Cycle Recoveries}

International trade has been a ascribed a critical role in short-run macroeconomic forecasts, especially so in small industrial and developing economies. The external sector has been largely viewed as an important catalyst for business cycle recoveries. According to Prasad and Gable (1998), the evidence on the quantitative importance of international trade in generating economic recoveries is, however, rather limited. This study therefore adopted their measure of the contribution of trade balance to output growth from business cycle troughs. This paper identified two historical business cycle troughs in 1985 and 2001 (see Figure 1). Table 4 shows the contribution of international trade balance and non-oil trade balance to output growth over different forecast horizons from cyclical troughs. At a one-year horizon from the 1985 cyclical troughs the trade balance had a negative contribution (-395.0E-08 percent) to growth but became positive in the second horizon and remained positive up to the eight horizon. The contribution of trade balance to recovery from the 2001 cyclical trough was positive from the first to the eighth horizon. But non-oil balance of trade had positive contribution to business cycle recovery only in the first horizons and became negative from the second to the eighth horizon. This is quit revealing. Although trade is important in business cycle recoveries there is no evidence that non-oil trade in Nigeria has contributed to economic recoveries. This is attributable to the fact that Nigeria's non-oil trade basket is made up of raw materials and agricultural exports on the one hand and manufactured and food imports on the other.

Table 4: The Contributions of International trade to Business Cycle Recoveries

\begin{tabular}{|c|c|c|c|c|c|c|c|c|}
\hline \multirow{4}{*}{$\begin{array}{c}\text { Cyclical } \\
\text { Troughs } \\
1985 \\
2001\end{array}$} & \multicolumn{4}{|c|}{$\begin{array}{c}\text { Contribution of trade balance to output growth } \\
\text { from troughs }\end{array}$} & \multicolumn{4}{|c|}{$\begin{array}{l}\text { Contribution of Non-Oil trade balance to } \\
\text { output growth from troughs }\end{array}$} \\
\hline & $\mathrm{t}+1$ & $t+2$ & $\mathrm{t}+4$ & $\mathrm{t}+8$ & $\mathrm{t}+1$ & $\mathrm{t}+2$ & $\mathrm{t}+4$ & $\mathrm{t}+8$ \\
\hline & $-3.95 E-08$ & $1.19 \mathrm{E}-07$ & $2.77 \mathrm{E}-07$ & $5.53 \mathrm{E}-07$ & $3.95 \mathrm{E}-08$ & $-7.90 \mathrm{E}-09$ & $-1.98 \mathrm{E}-07$ & $-1.26 \mathrm{E}-06$ \\
\hline & $2.66 \mathrm{E}-06$ & $1.99 \mathrm{E}-06$ & $1.56 \mathrm{E}-05$ & $7.85 \mathrm{E}-06$ & $4.40 \mathrm{E}-07$ & $-1.57 \mathrm{E}-06$ & $-1.97 \mathrm{E}-06$ & $-6.23 E-06$ \\
\hline
\end{tabular}

Source: Author's computation

Table 5: The Contributions of Exports to Business Cycle Recoveries

\begin{tabular}{|c|c|c|c|c|c|c|c|c|}
\hline \multirow{4}{*}{$\begin{array}{c}\text { Cyclical } \\
\text { Troughs } \\
1985 \\
2001\end{array}$} & \multicolumn{4}{|c|}{$\begin{array}{c}\text { Contribution of Exports to output growth from } \\
\text { troughs }\end{array}$} & \multicolumn{4}{|c|}{$\begin{array}{l}\text { Contribution of Non-Oil Exports to output } \\
\text { growth from troughs }\end{array}$} \\
\hline & $\mathrm{t}+1$ & $\mathrm{t}+2$ & $\mathrm{t}+4$ & $\mathrm{t}+8$ & $\mathrm{t}+1$ & $t+2$ & $\mathrm{t}+4$ & $\mathrm{t}+8$ \\
\hline & $-7.90 \mathrm{E}-08$ & $2.77 \mathrm{E}-07$ & 5.93E-09 & $2.33 \mathrm{E}-06$ & $-3.95 \mathrm{E}-08$ & $2.37 \mathrm{E}-07$ & $5.14 \mathrm{E}-07$ & $1.82 \mathrm{E}-06$ \\
\hline & $-1.09 \mathrm{E}-06$ & $4.42 \mathrm{E}-06$ & $1.98 \mathrm{E}-05$ & $1.70 \mathrm{E}-05$ & $-1.99 \mathrm{E}-06$ & $3.54 \mathrm{E}-06$ & $1.76 \mathrm{E}-05$ & $1.41 \mathrm{E}-05$ \\
\hline
\end{tabular}

Source: Author's computation 
In the context of the national income accounting identity, balance of trade seems to be the appropriate variable for examining the contribution of international trade to business cycle recoveries. However, an alternative argument is that export demand rather than net exports provides the catalyst for economic recovery. Increases in current and future exports due to strong external demand or exchange rate depreciation could trigger a recovery in domestic output. It is therefore possible that, with a concomitant increase in imports of investment goods and intermediate inputs, the trade balance could deteriorate despite the export stimulus to domestic demand. To examine the alternative hypothesis we now examine the contribution of exports and non-oil exports to output growth using the same measure as in trade balance. The results are reported on table 5 . The results revealed that business cycle recoveries in Nigeria beside the first horizons have relied not heavily on demand.

Cycle trough dates 1985 and 2001

Hodrick-Prescott Filter (lambda=100)

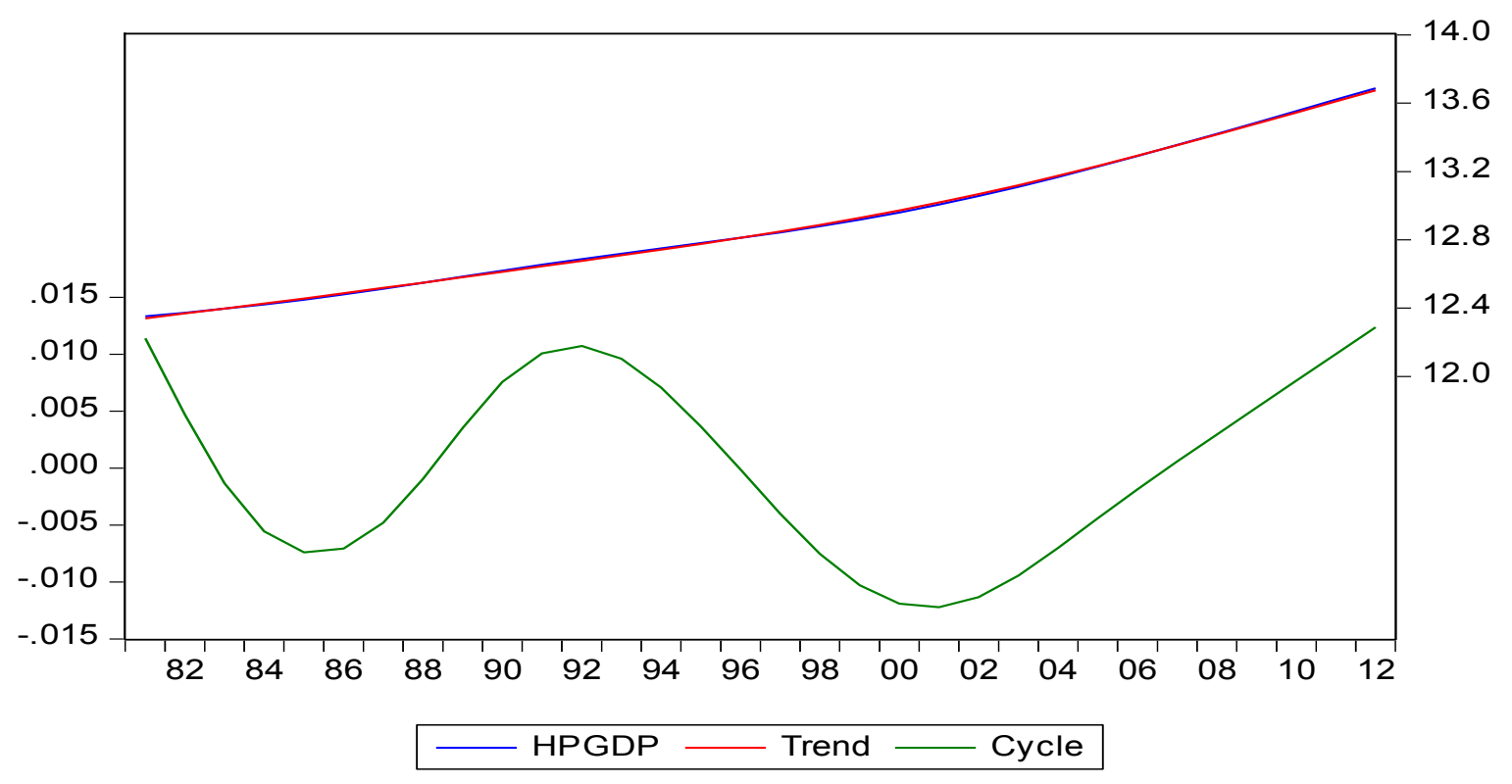

\section{Empirical Literature}

Akeem, U. O. (2011). focused on the workings of trade on Nigeria economic growth. Using the OLS techniques he concluded that foreign trade policies should be reexamined and competitive produces should be produced by local industries. Fidrmuc, et al (2011) analyzed globalization and business cycles in China and selected OECD countries using dynamic correlation analysis. They showed that dynamic correlations of business cycles of OECD countries and China are negative at business-cycle frequencies and positive for short-run developments. Furthermore, trade and financial flows of OECD countries and China reduce the degree of business cycle synchronization within the OECD area, especially at business-cycle frequencies. Thus, different degrees of participation in globalization can explain the differences between the business cycles of OECD countries.

Hao and Mathews, (2007) offered a procedure to identify industry cycles, and apply the procedure to the industrial data of three industries, namely semiconductors, PCs and FPDs. They compared the cycles with those suggested by industry experts in the corresponding industries, and the industry cycles across the three industries. They also examined the factors that contributed to the cyclical dynamics of the industries using vector autoregressive (VAR) models and established that the dynamics of aggregate economy and capacity are among the most significant drivers in the semiconductor industry cycle. 
Alege (2009) developed a small business cycle model in the spirit of Dynamic Stochastic General Equilibrium (DSGE) model for Nigeria with a view to examine the sources of business cycles and drawing implications for policy analysis. The paper focused on three policy shocks namely: monetary supply, technology and export supply on some macroeconomic aggregates. The study adopted the Nason and Cogley (1994) and Schorfheide (2000) models, but introduced export sector into the model with to capture the transmission channel of terms of trade. Using the Bayesian estimation technique he showed that the Nigerian business cycle was driven by both real and nominal shocks.

Using high-frequency transaction data for the three largest European markets (France, Germany and Italy), Caporale, et al (2010) showed the existence of an asymmetric relationship between market liquidity and trading imbalances: when quoted spreads rise (fall) and liquidity falls (increases) buy (sell) orders tend to prevail. Risk-averse market-makers, with inventorydepletion risk being their main concern, tend to quote wider (narrower) spreads when they think bond appreciation is more (less) likely to occur. It is also found that the probability of being in a specific regime is related to observable bond market characteristics, stock market volatility, macroeconomic releases and liquidity management operations of the monetary authorities.

Prasad (1999) developed a new empirical framework for analyzing the dynamics of trade balance in response to different types of macroeconomic shocks. The model provides a synthetic perspective on the conditional correlations between the business cycle and the trade balance that are generated by different shocks and attempted to reconcile these results with unconditional correlations found in the data. The results revealed that, in the post-Bretton Woods period, nominal shocks have been an important determinant of the forecast error variance for fluctuations on the trade balance in G-7 countries.

Prasad and Gable (1998) provided some new empirical perspectives on the relationship between international trade and macroeconomic fluctuations in industrial economies. First, a comprehensive set of stylized facts concerning fluctuations in trade variables and their determinants was presented. A measure of the quantitative importance of international trade for the propagation of domestic business cycles was then constructed, focusing on the role of external trade as a catalyst for cyclical recoveries. Finally, structural vector autoregressive models were used to characterize the joint dynamics of output, exchange rates, and trade variables in response to different types of macroeconomic shocks.

\section{Theoretical and Empirical Considerations}

This study adopts a multivariate structural time-series econometric model. The purpose was not only to identify different types of macroeconomic shocks but also to examine the effects of these shocks on relevant trade variables. The empirical framework is adopted from Prasad and Gable (1998). Prasad and Gable (1998) identified two main channels that determine the relationship between trade and cyclical output fluctuations. Holding external demand conditions constant, the first channel is through domestic demand and the second channel is through changes in exchange rates. This implies that the sources of business cycle fluctuations could have influence on the cyclical dynamics of trade. (i) Consider a situation where there is a domestic fiscal contraction that leads to a contraction in aggregate domestic demand. In the Mundell-Fleming framework with perfect capital mobility, this would lead to real exchange rate depreciation. In addition to the depressed domestic demand, this will cause a negative correlation between cyclical output and the trade balance (exports). Therefore both the domestic demand and real exchange rate effects work in one and the same direction. (ii) Consider a monetary contraction which would also tend to depress domestic demand. This 
would lead to increased exchange rate, thus creating an effect on the trade balance (exports) opposite to that of the domestic demand effect. The relative importance of these two effects is an empirical issue and would depend on various trade elasticities.

Another important issue is the persistence of fluctuations in both output and exchange rate. Highly persistent changes in output or exchange rate could have very different effects on trade dynamics compared to the effects of transitory changes in these variables (see Glick and Rogoff, 1995; and Phillips, 1996; Prasad and Gable, 1998). The implications of the persistence in output and exchange rate effects from different sources of macroeconomic shocks can be derived using macroeconomic models. This study exploits these theoretical considerations to derive a set of identifying restrictions to identify different types of macroeconomic shocks and to characterize the joint dynamics of output, exchange rates, and trade variables in response to these shocks.

In the empirical work, the study identified three types of shocks: supply, demand, and nominal shocks. The empirical model is identified using three long-run restrictions: that demand and nominal shocks have no long-run effects on the level of output while nominal shocks have no long-run effects on the level of the real exchange rate.

An important virtue of the identification approach is that the short-run dynamics are unconstrained. The identification scheme can therefore be evaluated by examining whether the short-run dynamics implied by the estimates of the empirical model appear reasonable and in accordance with the predictions of the theoretical model. Another feature of this identification approach is that it does not require us to take a stand on the causal ordering of the variables in the VAR. This is useful since there is no clear evidence that any of these variables is predetermined relative to the others in a Granger-causal sense.

The foregoing shows the limitations in models of trade (or current account) dynamics that focus solely on productivity shocks (e.g., Backus, Kehoe, and Kydland, 1992; and Elliott and Fatás, 1996). According to Prasad and Gable (1998) econometric models that distinguish only between real and nominal shocks (e.g., Lastrapes, 1992; and Robertson and Wickens, 1997) would also be inadequate for modeling trade balance dynamics since supply and demand shocks, which could both be viewed as real shocks, have different effects on the real exchange rate.

\section{Model Specification}

The model is adopted from the work of Prasad and Gable (1998). The methodology involves the estimation of a three-variable VAR comprising the first differences of output, real exchange rate, and the ratio of the trade balance (or exports or imports) to domestic output. Using a set of long-run restrictions, the VAR errors were transformed into a set of "fundamental" disturbances that have an economic interpretation-supply, demand, and nominal shocks. The short-run dynamics of the model are unconstrained and identification is achieved by imposing constraints on certain long-run multipliers in the system.

Since we have identified the exchange rate as the mechanism through which different shocks influence the relationship between external trade and the business cycle, exchange rates are included directly in the estimation in order to identify these shocks. Thus, the econometric approach is structural in that output fluctuations, variations in the real exchange rate, and changes in the trade variables are jointly determined in response to different shocks. 
The model for estimation is specified as follows:

$$
\Delta y_{t}=m+B_{1} \Delta y_{t-1}+B_{2} \Delta y_{t-2}+\ldots+B_{k} \Delta y_{t-k}+\epsilon_{t} \quad \text {. . . }
$$

Where yt is a column vector of three (3) variables, that is yt $=[\mathrm{rgdp}$ exr tb]' modeled in terms of its past values and ffirst difference, $\Delta \mathrm{yt}-1 . \Delta$ is first difference operator. Bi are $\mathrm{kx} \mathrm{k}$ matrix of coefficients, $\mathrm{m}$ is a $\mathrm{k} x 1$ vector of constants and $\epsilon_{-} \mathrm{t}$ is a vector of white noise processes with the following properties

$$
E\left(\epsilon_{t}\right)=0 \text { for all } t \quad E\left(\epsilon_{t} \epsilon_{s}^{\prime}\right)= \begin{cases}\Omega & s=t \\ 0 & s \neq t\end{cases}
$$

where the covariance matrix, $\Omega$ is assumed to be positive definite. Thus the $\epsilon^{\wedge '} \mathrm{~s}$ are serially uncorrelated but may be contemporaneously correlated. The lag length, $\mathrm{k}$ is determined empirically. To avoid the omission of relevant information estimation was done by iteration starting with the maximum lag length identified using the information criteria until the optimum model is arrived at-that is until the model becomes stable (no modulus or eigenvalue lies outside the unit circle). rgdp is the logarithm of real gross domestic product, exr is the logarithm of real exchange rate and TB is the ratio of trade balance to real GDP.

It is necessary to first determine the time-series properties of the variables entering the VAR. The model presented in Prasad and Kumar (1997) implies that relative output, the real effective exchange rate, and the ratio of the trade balance to GDP (and other trade ratios) are all stationary in first differences and that their levels are not cointegrated. Therefore estimation started with the preliminary tests for unit roots and cointegration to ensure the series are first difference stationary, I(1) and are not cointegrated in their level forms. The study relied on the impulse response functions and the forecast error variance decomposition to establish the responsiveness of output, exchange rate and trade balance to demand, DD, supply, SS and nominal NM shocks in the economy (see Greene, 2002 and Johnston \& Dinardo 1996 for a detailed discussion on impulse response function and forecast variance decomposition).

\section{RESULTS}

Results of the impulse responses of Trade Balance, Non-oil Trade Balance, Exports and Non-oil Exports to different types of shocks are presented on table 6. It is easy to see that trade balance and non-oil trade balance responds positively to nominal shock in the short-run but became negative in the long-run. Since nominal shocks leads to increases in output accompanied by exchange rate depreciations, this result suggests that the exchange rate effects on trade balance tend to dominant the output effects of these shocks only in the short-run. However, both Exports and Non-oil Exports responded positively to nominal shocks both in the shortand long-run suggesting that the exchange rate effects dominates the output effects both in the short- and long-run. This is in line with the findings of Eichenbaum and Evans (1995) that nominal shocks result in rapid and sharp exchange rate responses but have only very small and transitory effects on output. Demand shocks which lead to increase in output and exchange rate appreciation results in increases in trade balance and Non-oil Trade Balance but decreases in Exports and Non-oil Exports. On the other hand, the effects of supply shocks are mixed. Results of the forecast error variance decomposition presented on table 7 showed that nominal shocks explained more of the fluctuations in all of the trade variables followed by demand shocks in Trade Balance but by supply shocks in Non-oil trade Balance, Exports and Non-oil Exports. The percentages of volatility explained by these shocks became permanent in the long-run. Again this suggests the dominance of nominal shocks over output in explaining changes in trade variables even in the long-run.

\section{Table 6: Impulse responses}




\begin{tabular}{|c|c|c|c|c|c|c|}
\hline \multicolumn{4}{|c|}{ Trade Balance } & \multicolumn{3}{|c|}{ Non-oil Trade Balance } \\
\hline Horizon & SS & $\mathrm{DD}$ & $\mathrm{NM}$ & SS & $\mathrm{DD}$ & NM \\
\hline 1 & $2.53 \mathrm{E}-07$ & $3.84 \mathrm{E}-07$ & $2.84 \mathrm{E}-06$ & 0.10188 & 0.07638 & 0.62221 \\
\hline 5 & $5.32 \mathrm{E}-07$ & $2.41 \mathrm{E}-07$ & $2.11 \mathrm{E}-07$ & 0.01267 & 0.01420 & 0.03158 \\
\hline 10 & $-1.63 \mathrm{E}-07$ & $8.73 \mathrm{E}-08$ & $-1.91 \mathrm{E}-07$ & -0.0005 & -0.00055 & -0.00120 \\
\hline 20 & $1.36 \mathrm{E}-08$ & 5.62E-08 & $-4.23 \mathrm{E}-08$ & 2.09E-05 & $2.14 \mathrm{E} 05$ & 4.72E-05 \\
\hline 30 & $5.02 \mathrm{E}-09$ & $1.78 \mathrm{E}-08$ & $-1.51 \mathrm{E}-08$ & $-8.18 \mathrm{E}-07$ & $-8.37 \mathrm{E}-07$ & $-1.84 \mathrm{E}-06$ \\
\hline \multicolumn{4}{|c|}{ Exports } & \multicolumn{3}{|c|}{ Non-oil Exports } \\
\hline Horizon & $\mathrm{SS}$ & DD & NM & $\mathrm{SS}$ & DD & NM \\
\hline 1 & -0.33139 & -0.002516 & 1.486694 & -0.210057 & -0.013470 & 1.297489 \\
\hline 5 & 0.00599 & -0.003054 & 0.007019 & 0.005710 & -0.001925 & 0.003219 \\
\hline 10 & $6.12 \mathrm{E}-05$ & $-7.01 \mathrm{E}-06$ & $2.70 \mathrm{E}-05$ & $4.35 \mathrm{E}-05$ & $-6.35 \mathrm{E}-06$ & $1.70 \mathrm{E}-05$ \\
\hline 15 & $4.11 \mathrm{E}-07$ & $-8.58 \mathrm{E}-08$ & $2.41 \mathrm{E}-07$ & $2.98 \mathrm{E}-07$ & $-5.16 \mathrm{E}-08$ & $1.24 \mathrm{E}-07$ \\
\hline 20 & $3.05 \mathrm{E}-09$ & $-5.57 \mathrm{E}-10$ & $1.67 \mathrm{E}-09$ & $2.08 \mathrm{E}-09$ & $-3.51 \mathrm{E}-10$ & $8.56 \mathrm{E}-10$ \\
\hline
\end{tabular}

Source: Author's computation

Table 7: Error Variance Decomposition

\begin{tabular}{|c|c|c|c|c|c|c|}
\hline \multicolumn{4}{|c|}{ Trade Balance } & \multicolumn{3}{|c|}{ Non-oil Trade Balance } \\
\hline Horizon & SS & DD & NM & SS & DD & NM \\
\hline 1 & 0.7757 & 1.782 & 97.442 & 2.573 & 1.446 & 95.980 \\
\hline 5 & 6.4416 & 13.238 & 80.320 & 5.714 & 4.390 & 89.896 \\
\hline 10 & 8.3603 & 13.813 & 77.826 & 5.724 & 4.400 & 89.876 \\
\hline 15 & 8.4196 & 13.870 & 77.710 & 5.724 & 4.400 & 89.876 \\
\hline 20 & 8.4201 & 13.899 & 77.681 & 5.724 & 4.400 & 89.876 \\
\hline \multicolumn{4}{|c|}{ Exports } & \multicolumn{3}{|c|}{ Non-oil Exports } \\
\hline Horizon & SS & DD & NM & SS & DD & NM \\
\hline 1 & 4.733 & 0.0003 & 95.266 & 2.554 & 0.011 & 97.436 \\
\hline 5 & 7.472 & 0.110 & 92.418 & 3.807 & 0.112 & 96.082 \\
\hline 10 & 7.472 & 0.110 & 92.417 & 3.807 & 0.112 & 96.081 \\
\hline 15 & 7.472 & 0.110 & 92.417 & 3.807 & 0.112 & 96.081 \\
\hline 20 & 7.472 & 0.110 & 92.417 & 3.807 & 0.112 & 96.081 \\
\hline
\end{tabular}

Source: Author's computation

\section{CONCLUSION}

Results reflect the growing importance of trade (oil and Non-oil) to the Nigerian economy but oil-trade has been relatively more important. Net export was found to be relatively more volatile than aggregate output. Further, net non-oil export was less volatile than net oil export, and import was less volatile than export. Also, nominal effective exchange rate was more volatile than output and net non-oil export but less than net oil export. The unconditional correlation revealed that net export is countercyclical during recoveries and procyclical during periods of recession. Two historical business cycle troughs in 1985 and 2001 were identified but the paper found no evidence supporting the assertion that non-oil trade has contributed to 
economic recoveries in Nigeria. Furthermore nominal shocks dominate output shocks in explaining changes in trade variables.

\section{Recommendations}

Based on findings this study recommends as follows:

I. To better tap from the global resource base the monetary authority in Nigeria should apply sound monetary policy during periods of recession. This will stimulate output growth and quick recovery.

II. Since monetary policy effects on trade balance dominate only in the short-run monetary policy in Nigeria should focus on long-run output expansions.

\section{References}

Akeem, U. O. (2011). Performance Evaluation of Foreign Trade and Economic Growth in Nigeria. Research Journal of Finance and Accounting, 2(2),

Alege, P. O. (2009). A Business Cycle Model for Nigeria. Presentated at the African Econometric Society Conference, Abuja.

Backus, David K., and Patrick J. Kehoe, 1992, "International Evidence on the Historical Properties of Business Cycles," American Economic Review, Vol. 82 (September), pp. 864-88.

CBN (2013). Statistical Bulletin, Abuja

Caporale, G. M., A. Girardi, R. Isae, and P. Paesani (2010). Quoted Spreads and Trade Imbalance Dynamics in the European Treasury Bond Market. Economics and Finance Working Paper No. 10-28

Eichenbaum, Martin, and Charles L. Evans, 1995, "Some Empirical Evidence on the Effects of Monetary Policy Shocks on Exchange Rates," Quarterly Journal of Economics, Vol. 110 (November), pp. 975-1009.

Elliott, Graham, and Antonio Fatás, 1996, "International Business Cycles and the Dynamics of the Current Account," European Economic Review, Vol. 40 (February), pp. 361-87.

Fidrmuc, J., I. Korhonen and I. Bátorová (2011). China in the World Economy: Dynamic Correlation Analysis of Business Cycles. Center for Economic Institutions Working Paper Series

Glick, Reuven, and Kenneth Rogoff, 1995, "Global Versus Country-Specific Productivity Shocks and the Current Account," Journal of Monetary Economics, Vol. 35 (February), pp. 159-92.

Greene, W. H., 2002 Econometric Analysis, Prince Hall, New Jersey, 5th edition

Hao, T. and J. A. Mathews, (2007). Cyclical Dynamics in Three Industries. DRUID Working Paper No. 07-07

Johnston, J. and Dinardo, J. 1996, Econometric Methods, McGraw Hill, 4th edition

Lastrapes, William, 1992, "Sources of Fluctuations in Real and Nominal Exchange Rates," Review of Economics and Statistics, Vol. 74 (August), pp. 530-39.

Phillips, Kerk L., 1996, “The Cyclical Behavior of Net Exports: Temporary and Persistent Movements," Review of International Economics, Vol. 4 (February), pp. 79-89.

Prasad, E. S. (1999). International trade and the business cycle. The Economic Journal, 109(458), 588 - 606.

Prasad, E. S. and J. A. Gable (1998) International Evidence on the Determinants of Trade Dynamics. International Monetary Fund Staff Paper, 45(3) September

Prasad, Eswar S., and Manmohan Kumar, 1997, "International Trade and the Business Cycle" (unpublished; Washington: International Monetary Fund).

Robertson, Donald, and Mike R. Wickens, 1997, "Measuring Real and Nominal Macroeconomic Shocks and Their Transmission Under Different Monetary Systems," Oxford Bulletin of Economics and Statistics, Vol. 59 (February), pp. 5-27. 